\title{
Unexpected and Understandable Victory: Analysis and Evaluation of Trump's Campaign Strategy
}

\author{
Fangqiu Zhou \\ Bohai University \\ Jinzhou, Liaoning, China \\ Zhoufangqiu68822@163.com
}

\begin{abstract}
The election of Donald Trump as President of the United States is one of the biggest shocks of 2016. As one of the most controversial presidential candidates, he has been the subject of numerous analyses and comments since he announced his candidacy. Despite being the least favored candidate, the final results clearly show some advantages of his approach and strategy. There is no doubt that they are of great reference value and research value. Therefore, this article analyzes his campaign strategies from both positive and negative aspects. He is good at using the power of the media and popular mind to help his campaign. However, his election also exposed many crises in American political society. This paper does not evaluate Trump's personality and speech, but only analyzes his campaign strategy.
\end{abstract}

\section{Election}

Keywords-Campaign strategy; Trump; US Presidential

\section{INTRODUCTION}

There is no doubt that the most striking thing about the 2016 us presidential election is the performance of republican frontrunner Donald trump. When he announced his candidacy in 2015, almost everyone thought it was a joke. Even before the election results were announced, a lot of people did not believe he would succeed, especially most of mainstream media. However, the final answer, as we have seen, he entered the White House. In the process of the election, he has some unique strategies that are different from others. Although these methods have caused him to be controversial, they also have brought him higher approval ratings. His victory is surprising, but Trump has been successful in the presidential election as a political outsider who most people do not think he is good and suitable. His campaign strategy not only has the value of analysis and research, but also can provide reference for relevant political and commercial fields. This essay does not involve the value judgment of trump's views and personality, but only researches and discusses his campaign strategy.

\section{Positive STRATEGIES}

\section{A. Attracting the attention of mass media}

Trump's success has been judged to be a victory for communication, not a victory for politics. From the perspective of communication, maybe it is true. First of all, he is very good at using the power of the media, especially social media. His experience in business and entertainment have taught him how to become a media sensation and a source of excitement. Other candidates can use profound political experience and erudition, but their performance lacks diversity. However, Trump is different, and he is an abnormal man in the dissemination of style and content. His attacks and provocative words have long dominated the headlines, creating a powerful communication force on traditional media and social media. His bold statement also quickly attracts media attention and mass media coverage. For example, When Ryan, the chairman of the republican national convention, planned to talk about the house's agenda at a news conference in a week, reporters asked him all questions about Trump [1]. Simon states when he needs to improve his exposure, change the subject, or respond to an attack, he will say something outrageous to inspire new attention [2]. It is these absurd and even vulgar words that become a daily hot spot for the media that compete for attention. These reports have brought a lot of criticism and condemnation, but it has also made him more popular. The way that he used the media to raise public awareness by creating provocative public attention has greatly reduced the huge cost of media campaigns in traditional campaigns. According to statistics by Parkinson, Trump spends less than 1 percent of the money on television advertising on Jeb bush, another republican candidate [3]

\section{B. Good at using the power of social media}

Secondly, Trump has not only succeeded in attracting the attention of the mass media, but he also has a very successful personal media. According to Pfeiffer, Trump has a better understanding in how to harness the power of the Internet than any other candidate, and that is one of reasons why he has won. Research from the MIT media lab shows that the old influence hierarchy has been weakened and replaced by a new Mosaic effect, with social media playing a growing role. The study sees Trump as one of the most influential people and describe that he is a master on traditional media and social media. Trump also has said that owning twitter is like running a newspaper without losses. Since 2009, when Trump was a businessman, he has been using twitter to promote his brand. After 2015, he began to use the personal media to assist his campaign. In fact, Trump is not the first presidential candidate to make use of social media. But his aim is different from Obama's use of the Internet to raise money for himself in 2008. During the election campaign, in addition to promoting himself he also used twitter and other social media against Hillary Clinton, other competitors and media companies that support them. It can achieve the goal for control people attention. The American mainstream media has given him enough exposure 
because of considering the attention economy, but their attitude and evaluation are very terrible. Without social media, Trump may fail in a joint attack on traditional media. However, the propaganda effect of his millions of social media followers has defeated the traditional media's control over news and public opinion. His online advantage is staggering. According to Barbarou, in two months, just one social media platform, Twitter, he was mentioned 6.3 million times [4]. This number is three times more than Hillary Clinton.

\section{Accurately grasp the audience's psychology}

Furthermore, Trump has a very precise grasp of the psychology of the audience. All the time, people who have been able to voice in the mainstream media are highly educated and well-paid, urban elites. However, the majority of voters remain the ordinary public with a low level of literacy and income. But their voices are rarely heard. This is also the main reason why the mainstream media and elite have misjudged the election of trump. The frustration of the grassroots' restrictions on the right to speak has gradually transformed into a rebellious mentality with anti-intellectualism. They disdained the elite. Therefore, when Trump emerges as an image that is different from the traditional elite, the working class will have such an idea that he is our representative. His frank, outspoken, unfiltered conversation style was considered as brutish and reckless by the elite, but he gained a lot of grassroots fans. According to Goldberg, one thing that can be believed is that he has not consulted with any political advisor on how to talk [5]. He does not worry about how liberal editors of the New York Times or the Washington Post and conservative editors of the National Review look at him. In fact, most voters are not highly educated. They often have difficulty understanding complex public affairs and policy options, so they are not interested in foreign policies and ideologies that elites are good at talking about. They lack background knowledges needed for rational choice. They only pay attention to their own interests and hope to obtain fast and efficient solutions. When we observe the TV debate, we can see that when other candidates stated their policies and suggestions by enumerating a large number of figures and facts, the audience basically did not respond because the numbers made them feel boring and difficult to resonate with. However, as long as Trump speaks, he can continue to elicit laughter and applause in the audience with his amazing language and entertainment talent. In short, Trump won the support of many low-level voters successfully. This is because he fully understood their situation and accurately grasped their psychology.

\section{A successful marketing strategy}

Finally, a campaign that can achieve the goal is not only a success in communication, but also a marketing success. Marketing is a movement that changes people's cognition, and communication is the core factor that drives the marketing campaign. And in communication, the discourse system and slogan are the soul. Unlike other candidates, Trump's slogan is straightforward and does not have much rhetoric, but it is very easy to stir people's hearts. The political election surface is a candidate who is contending for the ballot. But it is essentially a marketing campaign. Candidates who can shake and win over people's hearts and change people's perceptions can win more votes. Trump's experience in the business world has made him an excellent marketer. In addition, his wealthy assets during his time as a businessman also laid down the material basis for the campaign so that he did not have to run for financial problems. Because of the huge cost of election campaigns, candidates are highly dependent on donations from major consortia and interest groups. This creates another worry for the American public that candidates will inevitably be affected and manipulated by special interest groups after they take office. It is difficult to provide benefits for ordinary people. The people's fears are not unreasonable. In order to prevent candidates from using their power or other improper means to raise money, this country has even enacted laws to limit and manage this behavior [6]. Trump's economic strategy shows that he can use his career to provide economic backing for himself and also provide employment opportunities for those who are in difficulties [7]. This will make people believe that when he is elected president will earnestly serve the people's welfare.

\section{NEGATIVE INFLUENCES}

\section{A. Social division and the rise of populism}

However, for Trump himself, his campaign may be called a victory. But, that puts others in a dilemma. His successful election actually exposed a crisis of secession and rising populism in American society. Firstly, after the Tea Party's decline in 2010, those far-right citizens in the United States, such as patriot militias, spontaneous border pickings and white supremacists, were constantly looking for a representative figure who could represent them. Now, they find Trump, a new president [8]. These far-right ideas once existed only in camps in some corners of the Internet and in the wilderness, but Trump took advantage of the populist wave to put them at the center of the US political debate. The sound of hatred and fear is often the loudest, and in these paranoid noises, the sounds of reason and sobriety are easily submerged. Murphy compared the United States in George Bush era to ancient Rome, believing that the United States might turn from a democracy to a dictatorship [9]. When mediocre politicians are no longer trusted by the voters, ordinary people will expect strong leader to appear. Trump, at least on the surface, seems to fit in with some people's perception of power. Today's United States is in danger of being split. On the one hand, we see many social progresses, such as the election of the first black president, the legalization of same-sex marriages, the mainstreaming of women's affirmative movements, and so on. On the other hand, the counteractions of social progress, such as racism, chauvinism, anti-intellectualism has also gradually emerged. In return, anti-intellectualism in the whole society is also one of reasons for trump's popularity. And one of the important challenges after Trump took office is how to face the United States in a divided state. 


\section{B. Audience emotions are manipulated}

In addition, Trump is a genius who manipulates public opinion. Unlike ordinary elites, Trump helped his real estate developer father to collect unpaid rents or took away tenants who default when he was a child. These experiences gave him the deeply contact to the people at the bottom. Also, his own business operations, whether real estate, hotels or casinos, employ tens of thousands of low-level workers. Therefore, he has a deep understanding of the behavior and thinking of the working class. The recent scandal over Facebook data breaches has led to the discovery of Cambridge Analytica, a UK data analysis firm. Britain's channel 4 reporter revealed how the company affected many political elections, including the US presidential election. They said that the content of the release may not be true, but it must be able to arouse people's strong feelings [10]. Although the behind-the-scenes operation behind the election is not unusual, it is also an example to show that Trump is very manipulative. But if Trump is devaluing the media and the elite to try to appeal to voters, this is his unique campaign strategy. How will he encourage the people to continue to support him after the successful election? This is a thought-provoking question. Of course, from the point of view of political communication, whether a political leader is successful depends not only on his policy decisions, but also on whether he can effectively communicate with the public. It is the effective principle of the leader to convey the message of government to the people. But if the trend goes to extremes and political rhetoric is simplified, it will lose the ability to communicate complex ideas and analyze complex problems. The language that he used and the way that he saw problems in home and abroad is simply unsettling. And whether he has the ability to handle complicated problems by suitable methods is something that people will wait and see in the next few years.

\section{CONCLUSION}

In conclusion, Trump's strategy shows that he knows how to win people's hearts when he takes part in political campaigns He does not take the unusual road, can accurately capture the psychological needs of the people, and is familiar with the situation of many ordinary people. Therefore, it is not a strange thing that he was elected. The 2016 US presidential election is also a dramatic political election, after the 2008 election that decide Obama as the first African-American president. As the New York Times said, Trump is very unique in American politics, even in modern western history [11]. But in any case, his business brand will appreciate again because of his unique political communication and marketing campaign. Trump will also enter the history of the us presidential campaign with his charismatic and controversial personal image.

\section{REFERENCES}

[1] Steinhauer, J. (2016). 'Why Donald Trump, Not Paul Ryan, Is Setting the GOP agenda', The New York Times, 6 March.

[2] Simon, J. (2016) Why journalists should be afraid of Trump's media strategy. Available at: https://www.cjr.org/first_person/why_journalists_should_be_afraid_of_t rumps_media_strategy.php (Accessed: 25 March 2018).

[3] Parkinson, H. (2015). 'Can Donald Trump social media genius take him all the way to the White House'? The Guardian, 23 December.

[4] Barbaro, M. (2015). 'How Donald Trump Uses Twitter (Hint: Impulsively)'. The New York Times, 10 May.

[5] Goldberg, J. (2015). 'What Republicans Can Learn from Donald Trump Straight-talk Express', New York Post, 1 September.

[6] Chen, W. (2000). 'Money in the United States election', Outlook Weekly, 11(45), pp.58-59.

[7] Song, X. (2016). 'A brief analysis of trump's campaign', Ability and Wisdom, 2016(20), pp.203-204

[8] Osnos, E. (2016) The Fearful and the Frustrated: Donald Trump's nationalist coalition takes shape for now. Available at: https://www.newyorker.com/magazine/2015/08/31/the-fearful-and-thefrustrated (Accessed: 28 March 2018)

[9] Murphy, C. (2008) Are We Rome? New York: Mariner Books

[10] Cambridge Analytica boasts of dirty tricks to swing elections (2018) Available at: https://www.theguardian.com/uknews/2018/mar/19/cambridge-analytica-execs-boast-dirty-tricks-honeytraps-elections (Accessed: 28 March 2018)

[11] Baker, K. (2016). 'Donald Trump Place'. The New York Times, 18 June 